\title{
Synthesis, Crystal Structures and Catalytic Oxidation of Manganese(III) Complexes Derived from Salen-Type Schiff Base $N, N$ '-Bis(5-nitrosalicylidene)ethane-1,2-diamine
}

\author{
Qing-Bin Li, Yong-Jun Han, Gan-Qing Zhao and Ling-Wei Xue* \\ College of Chemistry and Chemical Engineering, Pingdingshan University, Pingdingshan Henan 467000, P.R. China \\ *Corresponding author. E-mail: pdsuchemistry@163.com
}

Received: 05-04-2017

\begin{abstract}
Two mononuclear Schiff base manganese(III) complexes, $\left[\mathrm{MnL}\left(\mathrm{N}_{3}\right)\left(\mathrm{OH}_{2}\right)\right] \cdot \mathrm{CH}_{3} \mathrm{OH}(\mathbf{1})$ and $\left[\mathrm{MnL}(\mathrm{NCS})\left(\mathrm{OH}_{2}\right)\right] \cdot \mathrm{H}_{2} \mathrm{O}$ (2), where $\mathrm{L}$ is the dianionic form of $N, N^{\prime}$-bis(5-nitrosalicylidene)ethane-1,2-diamine, have been prepared and characterized by elemental analysis, IR and UV-Vis spectroscopy and single crystal X-ray diffraction. The $\mathrm{Mn}$ atom in each complex is in an octahedral coordination. Molecules of the complexes are linked through intermolecular hydrogen bonds. Catalytic properties for epoxidation of styrene by the complexes using $\mathrm{PhIO}$ and $\mathrm{NaOCl}$ as oxidant have been studied.
\end{abstract}

Keywords: Synthesis, Crystal structure, Schiff base, Manganese complex, Catalytic oxidation

\section{Introduction}

Schiff bases with salen-type are a kind of versatile ligands in coordination chemistry. ${ }^{1}$ In recent years extensive studies have been made on the chemistry of manganese(III) complexes derived from Schiff bases due to their important role in several metalloenzymes and to understand their catalytic activities in many organic reactions. ${ }^{2}$ Manganese complexes have interesting biological activities. ${ }^{3}$ The involvement of manganese in many biological systems is well established. Manganese(III) salen complexes are among the most efficient catalysts for the epoxidation of various olefins with high selectivity and yield. Epoxidation of olefins catalyzed by manganese(III) salen complexes has been studied extensively since Kochi and coworkers described in 1986 that they are highly effective, chemoselective, and stereoselective catalysts. ${ }^{4}$ Azide and thiocyanate are widely used because of their diverse binding modes which yield different types of molecules such as dimers, tetramers, one-, two-, or three-dimensional arrays. ${ }^{5}$ In order to investigate the influence of the azide and thiocyanate ligands on manganese(III) complexes with tetradentate Schiff base ligands, as well as the catalytic oxidation property, we report here the synthesis, characterization, crystal structures and catalytic oxidation property of two new complexes $\left[\mathrm{MnL}\left(\mathrm{N}_{3}\right)\left(\mathrm{OH}_{2}\right)\right]$.
$\mathrm{CH}_{3} \mathrm{OH}(\mathbf{1})$ and $\left[\mathrm{MnL}(\mathrm{NCS})\left(\mathrm{OH}_{2}\right)\right] \cdot \mathrm{H}_{2} \mathrm{O}(\mathbf{2})$, where $\mathrm{L}$ is the dianionic form of $N, N^{\prime}$-bis(5-nitrosalicylidene)ethane1,2-diamine.

\section{Experimental}

\section{1. Materials and Methods}

Manganese perchlorate, sodium azide and ammonium thiocyanate obtained from commercial sources were of analytical grade and used without further purification. 5-Nitrosalicylaldehyde and $N, N$ '-ethane-1,2-diamine were purchased from Aldrich. The Schiff base $\mathrm{H}_{2} \mathrm{~L}$ was prepared according to the literature method. ${ }^{6}$ Iodosylbenzene (PhIO) was prepared by the hydrolysis of iodobenzenediacetate. ${ }^{7}$ Styrene and styrene oxide were purchased from Aldrich and used in epoxidation experiment without further purification. The styrene oxide was used as standard sample in GC analysis. CHN elemental analyses were carried out with a Finnigan EA 1112 elemental analyzer. IR spectra were performed on a Nicolet 470 spectrometer with $\mathrm{KBr}$ pellets in the $4000-400 \mathrm{~cm}^{-1}$ region. UV-Vis spectra were recorded on a Lambda 35 spectrometer. The crystal determination was carried out on a Bruker SMART 1000 CCD area diffractometer. GC experiments were performed with Agilent 5977A Network 
GC systems. ${ }^{1} \mathrm{H}$ and ${ }^{13} \mathrm{C}$ NMR data were recorded on a Bruker $300 \mathrm{MHz}$ instrument.

Caution! Perchlorate and azide complexes of metal ions are potentially explosive. Only a small amount of material should be prepared, and it should be handled with caution.

\section{2. Synthesis of $\left[\mathrm{MnL}\left(\mathrm{N}_{3}\right)\left(\mathrm{OH}_{2}\right)\right] \cdot$ $\mathrm{CH}_{3} \mathrm{OH}$}

The mixture of $\mathrm{NaN}_{3}(0.065 \mathrm{~g}, 1.00 \mathrm{mmol})$ and $\mathrm{Mn}\left(\mathrm{ClO}_{4}\right)_{2} \cdot 6 \mathrm{H}_{2} \mathrm{O}(0.362 \mathrm{~g}, 1.00 \mathrm{mmol})$ in $50 \mathrm{~mL}$ methanol was stirred for half an hour with heating, then $\mathrm{H}_{2} \mathrm{~L}(0.358 \mathrm{~g}, 1.00 \mathrm{mmol})$ was added to the solution and the reaction continued to stirred for $1 \mathrm{~h}$. After filtration, the deep brown filtrate was allowed to stand at room temperature for a week to deposit brown crystals of the complex in $37.2 \%$ yield. Anal. Calc. for $\mathrm{C}_{17} \mathrm{H}_{18} \mathrm{MnN}_{7} \mathrm{O}_{8}$ : C, 40.57; H, 3.60; N, 19.48. Found: C, 40.38; H, 3.72; N, $19.35 \%$. IR data $\left(\mathrm{KBr} ; \mathrm{v}, \mathrm{cm}^{-1}\right): 3450$ (m, br), 2041 (s), 1634 (s), 1601 (s), 1559 (w), 1501 (m), 1451 (s), 1343 (w), 1301 (m), 1093 (s), 948 (m), 853 (s), 799 (w), 693 $(\mathrm{w}), 545(\mathrm{~s})$. UV-Vis data in acetonitrile $\left[\lambda_{\max }(\mathrm{nm})\right]: 298$, 343.

\section{3. Synthesis of $\left[\mathrm{MnL}(\mathrm{NCS})\left(\mathrm{OH}_{2}\right)\right] \cdot \mathrm{H}_{2} \mathrm{O}$}

The mixture of $\mathrm{NH}_{4} \mathrm{NCS}(0.076 \mathrm{~g}, 1.0 \mathrm{mmol})$ and $\mathrm{Mn}\left(\mathrm{ClO}_{4}\right)_{2} \cdot 6 \mathrm{H}_{2} \mathrm{O}(0.362 \mathrm{~g}, 1.00 \mathrm{mmol})$ in $50 \mathrm{~mL}$ methanol was stirred for half an hour with heating, then $\mathrm{H}_{2} \mathrm{~L}(0.358 \mathrm{~g}, 1.00 \mathrm{mmol})$ was added to the solution and the reaction continued to stirred for $1 \mathrm{~h}$. After filtration, the deep brown filtrate was allowed to stand at room temperature for a week to deposit brown crystals of the complex in $45.0 \%$ yield. Anal. Calc. for $\mathrm{C}_{17} \mathrm{H}_{16} \mathrm{MnN}_{5} \mathrm{O}_{8} \mathrm{~S}$ : C, 40.40; H, 3.19; N, 13.86. Found: C, 40.53; H, 3.33; N, 13.70\%. IR data $\left(\mathrm{cm}^{-1}\right): 3445$ (m, br), 2067 (s), 1634 (s), 1601 (s), 1561 (w), 1500 (m), 1446 (s), 1345 (w), 1298 (w), 1102 (s), 993 (m), 951 (m), 855 (s), 799 (w), 696 $(\mathrm{w}), 547(\mathrm{~s})$. UV-Vis data in acetonitrile $\left[\lambda_{\max }(\mathrm{nm})\right]: 298$, 343.

\section{4. X-ray Diffraction}

Suitable single crystals of the complexes were mounted at the top of glass fibres and scanned on a Bruker SMART $1000 \mathrm{CCD}$ area diffractometer with a $\mathrm{MoK \alpha}$ radiation $(\lambda=0.71073 \AA)$ at 298(2) K. The unit cell dimensions were obtained with the least-squares refinements and the structures were solved and refined by direct methods with SHELXTL-97 program. ${ }^{8}$ The final refinement was performed by full-matrix least-squares techniques with anisotropic thermal parameters for the non-hydrogen atoms on $F^{2}$. The water and hydroxyl hydrogen atoms (O3 and $\mathrm{O} 8$ for $\mathbf{1}$ and 2) were located from difference Fourier maps, with $\mathrm{O}-\mathrm{H}$ and $\mathrm{H} \cdots \mathrm{H}$ distances restrained to $0.85(1)$ and 1.37(2) $\AA$, respectively. The remaining hydrogen atoms were placed geometrically, with $U_{\text {iso }}(\mathrm{H})$ restrained to $1.2 U_{\text {eq }}(\mathrm{C})$ and $1.5 U_{\text {eq }}\left(\mathrm{C}_{\text {methyl }}\right)$. Multi-scan absorption correction was applied by using the SADABS program. ${ }^{9}$ Crystallographic data are summarized in Table 1.

Table 1. Crystal and structure refinement data for the complexes

\begin{tabular}{|c|c|c|}
\hline & 1 & 2 \\
\hline Formula & $\mathrm{C}_{17} \mathrm{H}_{18} \mathrm{MnN}_{7} \mathrm{O}_{8}$ & $\mathrm{C}_{17} \mathrm{H}_{16} \mathrm{MnN}_{5} \mathrm{O}_{8} \mathrm{~S}$ \\
\hline FW & 503.32 & 505.35 \\
\hline Crystal system & Monoclinic & Monoclinic \\
\hline Space group & $P 2_{1} / n$ & $P 2_{1} / c$ \\
\hline$a / \AA$ & $13.8160(9)$ & $13.936(2)$ \\
\hline$b / \AA$ & $12.2649(8)$ & $12.707(2)$ \\
\hline$c / \AA$ & $13.8286(9)$ & $13.067(2)$ \\
\hline$\beta /^{\circ}$ & $117.280(1)$ & $116.187(2)$ \\
\hline$V / \AA^{3}$ & $2082.7(2)$ & $2076.5(5)$ \\
\hline$Z$ & 4 & 4 \\
\hline$\mu / \mathrm{mm}^{-1}\left(\mathrm{Mo}-\mathrm{K}_{\alpha}\right)$ & 0.696 & 0.793 \\
\hline Reflections/parameters & $11921 / 308$ & $11814 / 301$ \\
\hline Independent reflections & 4529 & 4516 \\
\hline Obs. reflections $[I \geq 2 \sigma(I)]$ & 3836 & 3623 \\
\hline Restraints & 4 & 6 \\
\hline$F(000)$ & 1032 & 1032 \\
\hline Goodness of fit on $\mathrm{F}^{2}$ & 1.081 & 1.050 \\
\hline$R_{1}, w R_{2}[I \geq 2 \sigma(I)]^{\mathrm{a}}$ & $0.0297,0.0816$ & $0.0411,0.1148$ \\
\hline$R_{1}, w R_{2}(\text { all data })^{\mathrm{a}}$ & $0.0380,0.0890$ & $0.0538,0.1294$ \\
\hline
\end{tabular}

$$
{ }^{\mathrm{a}} R_{1}=\Sigma|| F_{o}|-| F_{c} \||\Sigma| F_{o} \mid, w R_{2}=\left[\Sigma w\left(F_{o}^{2}-F_{c}^{2}\right)^{2} / \Sigma w\left(F_{o}^{2}\right)^{2}\right]^{1 / 2}
$$

\section{5. General Method for Styrene Oxidation}

The oxidation reactions were carried out at room temperature in acetonitrile under nitrogen atmosphere with constant stirring. The composition of the reaction mixture was $2.00 \mathrm{mmol}$ of styrene, $2.00 \mathrm{mmol}$ of chlorobenzene (internal standard), $0.10 \mathrm{mmol}$ of $\mathrm{Mn}$ (III) complex (catalyst) and $2.00 \mathrm{mmol}$ iodosylbenzene or sodium hypochlorite (oxidant) in $5.00 \mathrm{~mL}$ freshly distilled acetonitrile. When the oxidant was sodium hypochlorite, the solution was buffered to $\mathrm{pH} 11.2$ with $\mathrm{NaH}_{2} \mathrm{PO}_{4}$ and $\mathrm{NaOH} .{ }^{10}$ The composition of reaction medium was determined by GC with styrene and styrene epoxide quantified by the internal standard method (chlorobenzene). All other products detected by GC were mentioned as others. For each complex the reaction time for maximum epoxide yield was determined by withdrawing periodically $0.1 \mathrm{~mL}$ aliquots from the reaction mixture and this time was used to monitor the efficiency of the catalyst on performing at least two independent experiments. Blank experiments with each oxidant and using the same experimental conditions except catalyst were also performed. 


\section{Results and Discussion}

Complexes $\mathbf{1}$ and $\mathbf{2}$ were synthesized according to the procedure as described in Scheme 1. angles of $178.8(2)^{\circ}$ for $\mathbf{1}$ and $177.8(3)^{\circ}$ for $\mathbf{2}$. The plane defined by $\mathrm{N} 1-\mathrm{N} 2-\mathrm{O} 1-\mathrm{O} 2$ forms dihedral angles of $17.9(3)^{\circ}$ and $13.1(3)^{\circ}$ for 1 , and $14.8(3)^{\circ}$ and $16.7(3)^{\circ}$ for 2, with $\mathrm{C} 1-\mathrm{C} 6$ and $\mathrm{C} 11-\mathrm{C} 16$ benzene rings, respectively.<smiles>O=[N+]([O-])c1ccc(O)c(/C=N/CC/N=C/c2cc([N+](=O)[O-])ccc2O)c1</smiles>

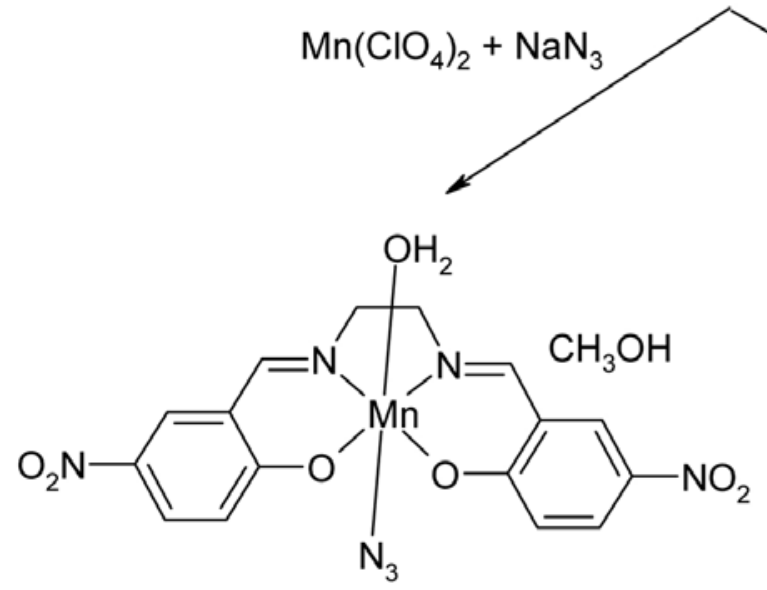

Scheme 1. The synthetic procedure for the complexes

\section{1. Crystal Structure Description of the Dioxomolybdenum Complexes}

The structures of complexes $\mathbf{1}$ and $\mathbf{2}$ are shown in Figs. 1 and 2, respectively. Selected bond lengths and bond angles are listed in Table 2. The distances and angles related to the hydrogen bonding are listed in Table 3 .

Single-crystal X-ray structural analysis revealed that both complexes are similar. The asymmetric unit of each complex contains a mononuclear manganese complex molecule and a solvent molecule, viz. methanol for $\mathbf{1}$ and water for $\mathbf{2}$. The $\mathrm{Mn}$ atoms in the complexes are in octahedral environment consisting of the $\mathrm{N}_{2} \mathrm{O}_{2}$ donor set of the Schiff base ligands, the oxygen donor of water ligands, and the terminal nitrogen donor of the azide or thiocyanate ligand. The equatorial plane of the octahedral coordination is defined by the phenolate oxygen and imino nitrogen of the Schiff base ligands, with the Mn atoms deviate from the least-squares planes by 0.061 (2) $\AA$ for $\mathbf{1}$ and 0.089 (2) $\AA$ for 2 . The $\mathrm{Ni}-\mathrm{N}$ and $\mathrm{Ni}-\mathrm{O}$ bond lengths are comparable to the corresponding values observed in manganese complexes with Schiff base ligands. ${ }^{11}$ The axial Mn1-N5 and Mn1-O3 bond lengths are longer than the equatorial bonds, which is caused by Jahn-Teller effects expected for $\mathrm{d}^{4}$ high spin manganese(III) systems. ${ }^{12}$ The azide and thiocyanate ligands are quasi-linear, with
Table 2. Selected bond lengths $(\AA)$ and angles $\left(^{\circ}\right)$ for the complexes

\begin{tabular}{|c|c|c|c|}
\hline 1 & & & \\
\hline$\overline{\mathrm{Mn} 1-\mathrm{O} 1}$ & $1.8745(12)$ & $\mathrm{Mn} 1-\mathrm{O} 2$ & $1.8844(12)$ \\
\hline Mn1-N1 & $1.9737(14)$ & $\mathrm{Mn} 1-\mathrm{N} 2$ & $1.9766(13)$ \\
\hline Mn1-O3 & $2.3031(15)$ & Mn1-N5 & $2.2288(17)$ \\
\hline $\mathrm{O} 1-\mathrm{Mn} 1-\mathrm{O} 2$ & $91.61(5)$ & O1-Mn1-N1 & $91.80(6)$ \\
\hline $\mathrm{O} 2-\mathrm{Mn} 1-\mathrm{N} 1$ & $174.92(6)$ & $\mathrm{O} 1-\mathrm{Mn} 1-\mathrm{N} 2$ & $174.25(6)$ \\
\hline $\mathrm{O} 2-\mathrm{Mn} 1-\mathrm{N} 2$ & $92.72(6)$ & N1-Mn1-N2 & $83.63(6)$ \\
\hline O1-Mn1-N5 & $95.91(6)$ & O2-Mn1-N5 & $93.58(6)$ \\
\hline N1-Mn1-N5 & $89.82(7)$ & N2-Mn1-N5 & $87.60(6)$ \\
\hline O1-Mn1-O3 & $89.72(6)$ & $\mathrm{O} 2-\mathrm{Mn} 1-\mathrm{O} 3$ & $90.32(6)$ \\
\hline N1-Mn1-O3 & $85.93(6)$ & N2-Mn1-O3 & $86.47(6)$ \\
\hline N5-Mn1-O3 & $173.05(6)$ & & \\
\hline 2 & & & \\
\hline$\overline{\mathrm{Mn} 1-\mathrm{O} 1}$ & $1.8830(16)$ & $\mathrm{Mn} 1-\mathrm{O} 2$ & $\overline{1.9107(16)}$ \\
\hline Mn1-N1 & $1.981(2)$ & $\mathrm{Mn} 1-\mathrm{N} 2$ & $1.979(2)$ \\
\hline $\mathrm{Mn} 1-\mathrm{O} 3$ & $2.297(2)$ & Mn1-N5 & $2.205(3)$ \\
\hline $\mathrm{O} 1-\mathrm{Mn} 1-\mathrm{O} 2$ & $93.49(7)$ & $\mathrm{O} 1-\mathrm{Mn} 1-\mathrm{N} 2$ & $172.49(9)$ \\
\hline $\mathrm{O} 2-\mathrm{Mn} 1-\mathrm{N} 2$ & $91.63(8)$ & O1-Mn1-N1 & $91.36(8)$ \\
\hline O2-Mn1-N1 & $172.62(8)$ & N2-Mn1-N1 & $83.04(9)$ \\
\hline O1-Mn1-N5 & 92.31(9) & O2-Mn1-N5 & $94.78(9)$ \\
\hline N2-Mn1-N5 & $92.74(10)$ & N1-Mn1-N5 & $90.58(10)$ \\
\hline $\mathrm{O} 1-\mathrm{Mn} 1-\mathrm{O} 3$ & $91.55(8)$ & $\mathrm{O} 2-\mathrm{Mn} 1-\mathrm{O} 3$ & $89.49(8)$ \\
\hline N2-Mn1-O3 & $83.00(8)$ & $\mathrm{N} 1-\mathrm{Mn} 1-\mathrm{O} 3$ & $84.81(8)$ \\
\hline N5-Mn1-O3 & $174.06(9)$ & & \\
\hline
\end{tabular}

In the crystal structure of $\mathbf{1}$, the manganese complex molecules are linked by water molecules through intermolecular hydrogen bonds of $\mathrm{O}-\mathrm{H} \cdots \mathrm{O}$ to form dimers. 
The dimers are then connected via $\mathrm{O}-\mathrm{H} \cdots \mathrm{N}$ hydrogen bonds to form 2D layers (Fig. 3). In the crystal structure of $\mathbf{2}$, the manganese complex molecules are linked by water molecules through intermolecular hydrogen bonds of $\mathrm{O}-\mathrm{H}$... O to form dimers. The dimers are then connected by water molecules to form 2D layers (Fig. 4).

Table 3. Distances $(\AA)$ and angles $\left(^{\circ}\right)$ involving hydrogen bonding of the complexes.

\begin{tabular}{|c|c|c|c|c|}
\hline$\overline{D-\mathrm{H} \cdots A}$ & $d(D-\mathrm{H})$ & $d(\mathrm{H} \cdots A)$ & $d(D \cdots A)$ & $\operatorname{Angle}(D-\mathrm{H} \cdots A)$ \\
\hline \multicolumn{5}{|l|}{$\overline{1}$} \\
\hline $\mathrm{O} 3-\mathrm{H} 3 \mathrm{~A} \cdots \mathrm{O} 8$ & $0.85(1)$ & $1.88(1)$ & $2.716(2)$ & $168(3)$ \\
\hline $\mathrm{O} 3-\mathrm{H} 3 \mathrm{~B} \cdots \mathrm{O} 2^{\mathrm{i}}$ & $0.84(1)$ & $2.16(1)$ & $2.967(2)$ & $163(3)$ \\
\hline $\mathrm{O} 3-\mathrm{H} 3 \mathrm{~B} \cdots \mathrm{O} 1^{\mathrm{i}}$ & $0.84(1)$ & $2.60(2)$ & $3.188(2)$ & $128(2)$ \\
\hline $\mathrm{O} 8-\mathrm{H} 8 \cdots \mathrm{N} 5^{\mathrm{ii}}$ & $0.87(1)$ & $1.96(1)$ & $2.185(3)$ & $167(3)$ \\
\hline $\mathrm{O} 8-\mathrm{H} 8 \cdots \mathrm{N}^{\mathrm{ii}}$ & $0.87(1)$ & 2.61(1) & $3.461(3)$ & $167(3)$ \\
\hline \multicolumn{5}{|l|}{2} \\
\hline $\mathrm{O} 3-\mathrm{H} 3 \mathrm{~A} \cdots \mathrm{O} 8$ & $0.85(1)$ & $1.88(1)$ & $2.696(30$ & $162(3)$ \\
\hline $\mathrm{O} 3-\mathrm{H} 3 \mathrm{~B} \cdots \mathrm{O} 2^{\mathrm{iii}}$ & $0.85(1)$ & $1.99(1)$ & $2.819(3)$ & $164(3)$ \\
\hline
\end{tabular}

Symmetry codes: (i) $1-x,-y,-z$; (ii) $3 / 2-x, 1 / 2+y, 1 / 2-z$; (iii) $x, 2-y, 1-z$.

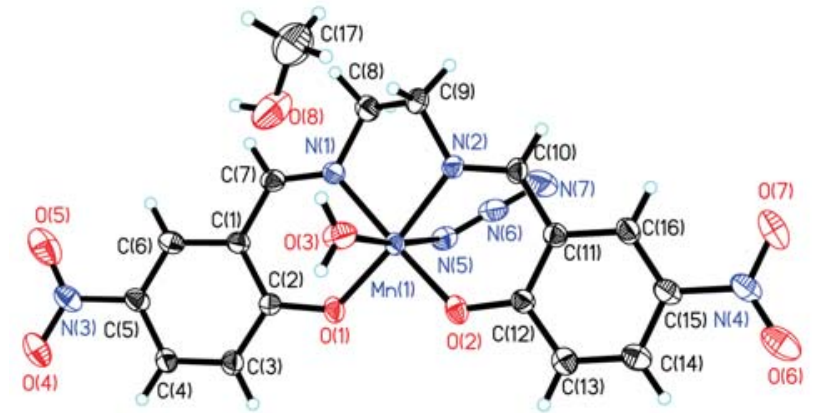

Figure 1. Molecular structure of $\mathbf{1}$ at $30 \%$ probability thermal ellipsoids.

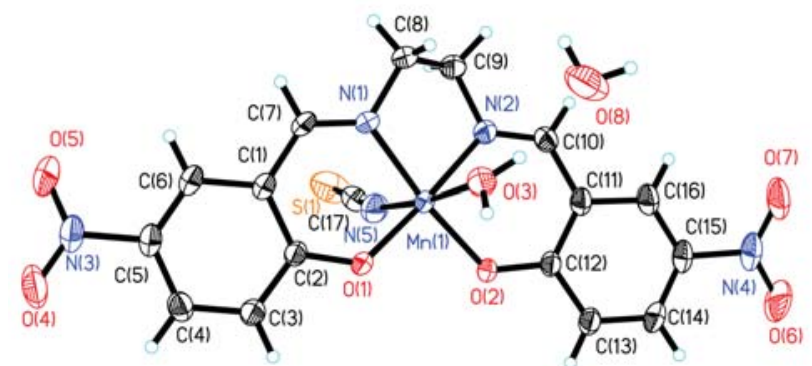

Figure 2. Molecular structure of $\mathbf{2}$ at 30\% probability thermal ellipsoids.

\section{2. Infrared and Electronic Spectra}

IR spectra of the manganese(III) complexes are very similar. The complexes exhibit broad bands cen-

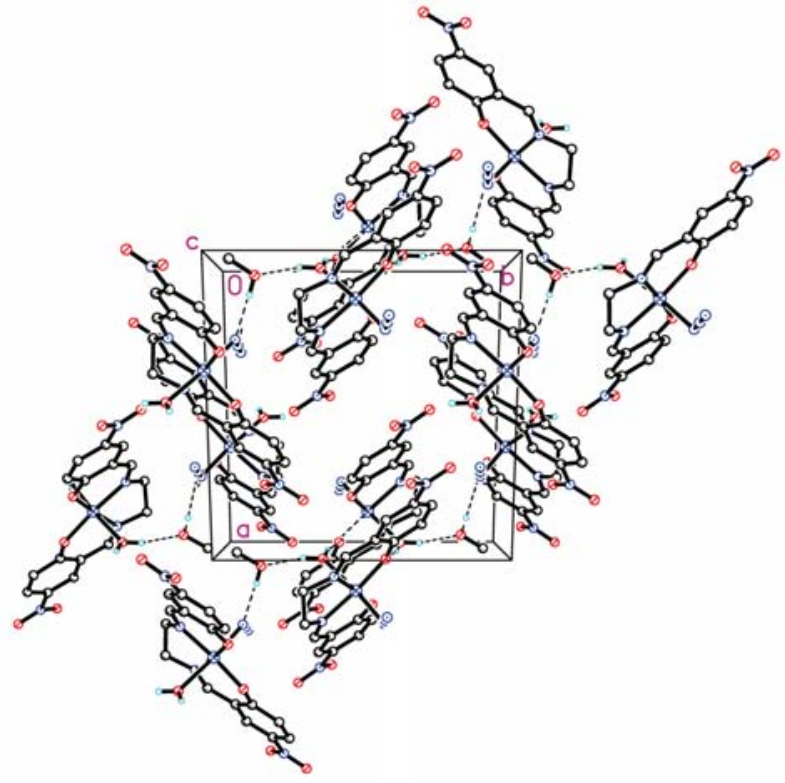

Figure 3. Molecular packing of 1. Intermolecular hydrogen bonds are shown as dashed lines.

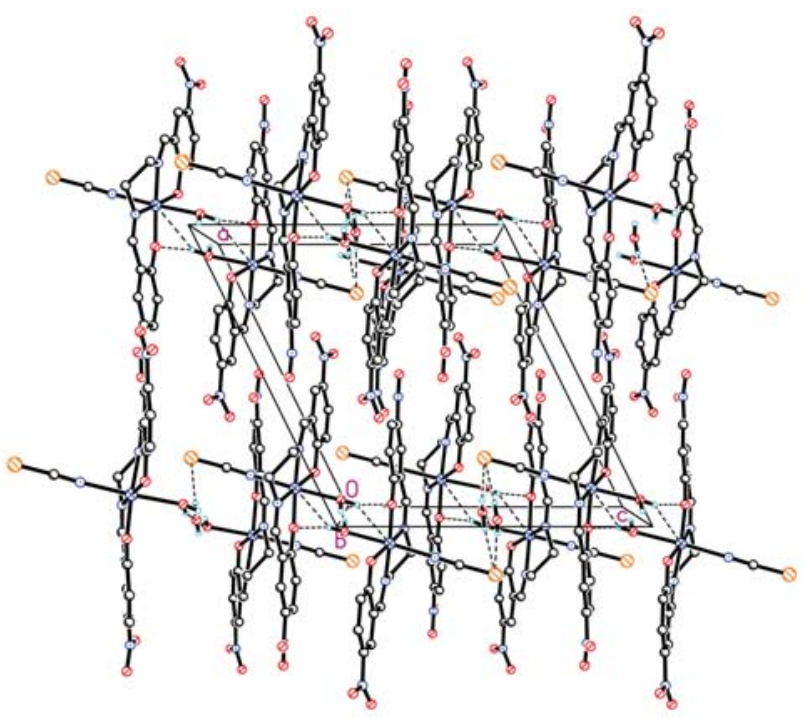

Figure 4. Molecular packing of 2. Intermolecular hydrogen bonds are shown as dashed lines.

tered at $c a .3450 \mathrm{~cm}^{-1}$, indicative of the presence of coordinated and/or lattice water or methanol molecules. The strong bands indicative of $v(\mathrm{C}=\mathrm{N})$ are located at $1601 \mathrm{~cm}^{-1}$. The shift of the strong bands towards lower frequencies, compared to the spectrum of the free Schiff base, is consistent with the imino nitrogen coordination. The asymmetric and symmetric vibrations of the nitro groups are located at about 1451 and $1301 \mathrm{~cm}^{-1}$, respectively. The intense absorption for the stretching vibrations of the azide ligand in $\mathbf{1}$ and the thiocyanate ligand in 2 are observed at $2041 \mathrm{~cm}^{-1}$ and $2067 \mathrm{~cm}^{-1}$, respectively. 
UV-Vis spectra for diluted acetonitrile solutions of the complexes were registered. The absorption at $298 \mathrm{~nm}$ and $343 \mathrm{~nm}$ are due to the benzene and azomethine chromophore $\pi \rightarrow \pi^{*}$ transitions, respectively.

\section{3. Oxidation of Styrene by the Complexes}

Oxidation of styrene was carried out at room temperature with the complexes as the catalysts and $\mathrm{PhIO}$ and $\mathrm{NaOCl}$ as oxidants. The deep brown color of the solutions containing the complexes and the substrate was intensified after the addition of oxidant indicating the formation of oxo-metallic intermediates of the catalysts. ${ }^{13}$ After completion of oxidation reaction of the alkene, the solution regains its initial color which suggests that the regeneration of the catalysts takes place. The percentage of conversion of styrene, selectivity for styrene oxide, yield of styrene oxide for each complex and reaction time to obtain maximum yield using both the oxidants are given in Table 4.

The two complexes as catalysts convert styrene most efficiently in the presence of $\mathrm{PhIO}$ or $\mathrm{NaOCl}$. It is easily observed that there is no obvious difference for the catalytic properties between the two complexes, as a result of similar structures. The complexes are selective towards the formation of styrene epoxide. When the reactions were carried out with $\mathrm{PhIO}$, styrene conversions are $89 \%$ and $87 \%$ for $\mathbf{1}$ and $\mathbf{2}$, respectively. When the reactions were carried out with $\mathrm{NaOCl}$, styrene conversions are $75 \%$ and $76 \%$ for $\mathbf{1}$ and $\mathbf{2}$, respectively. ${ }^{1} \mathrm{H}$ NMR data for the product $\left(\delta, \mathrm{ppm}, \mathrm{CDCl}_{3}\right): 2.76(\mathrm{t}, 1 \mathrm{H}), 3.09(\mathrm{t}, 1 \mathrm{H})$, $3.82(\mathrm{t}, 1 \mathrm{H}), 7.28(\mathrm{~m}, 5 \mathrm{H}) .{ }^{13} \mathrm{C}$ NMR data for the product $\left(\delta, \mathrm{ppm}, \mathrm{CDCl}_{3}\right): 51.0,52.3,125.5,128.1,128.5,137.7$. The catalytic properies of the complexes are comparable to those of the molybdenum complexes. ${ }^{14}$

Table 4. Catalytic results

\begin{tabular}{ccccccc}
\hline & $\begin{array}{c}\text { Time } \\
\text { (h) }\end{array}$ & Oxidant & \multicolumn{4}{c}{$\begin{array}{c}\text { Conversion Epoxide Selectivity (\%) } \\
\text { (\%) }\end{array}$} \\
\hline 1 & 2.0 & PhIO & 89 & 77 & 83 & 17 \\
& 3.0 & NaOCl & 75 & 62 & 80 & 20 \\
2 & 2.0 & PhIO & 87 & 79 & 85 & 15 \\
& 3.0 & NaOCl & 76 & 65 & 78 & 22 \\
\hline
\end{tabular}

\section{Supplementary Mateiral}

1060283 for $\mathbf{1}$, and 1060284 for $\mathbf{2}$ contain the supplementary crystallographic data for this paper. These data can be obtained free of charge at http://www.ccdc.cam. ac.uk/const/retrieving.html or from the Cambridge Crystallographic Data Centre (CCDC), 12 Union Road, Cambridge CB2 1EZ, UK; fax: +44(0)1223-336033 or email: deposit @ ccdc.cam.ac.uk.

\section{Acknowledgments}

This research was supported by the National Sciences Foundation of China (No. 20676057 and 20877036) and Top-class foundation of Pingdingshan University (No. 2008010).

\section{References}

1. (a) L. K. Das, C. J. Gomez-Garcia, A. Ghosh, Dalton Trans. 2015, 44, 1292-1302; https://doi.org/10.1039/C4DT02823F

(b) S. Chakraborty, C. R. Bhattacharjee, P. Mondal, S. K. Prasad, D. S. S. Rao, Dalton Trans. 2015, 44, 7477-7488. https://doi.org/10.1039/C4DT03989K

2. (a) M. Z. Rong, J. Wang, Y. P. Shen, J. Y. Han, Catal. Commun. 2012, 20, 51-53; https://doi.org/10.1016/j.catcom.2011.11.035

(b) S. Majumder, S. Hazra, S. Dutta, P. Biswas, S. Mohanta, Polyhedron 2009, 28, 2473-2479;

https://doi.org/10.1016/j.poly.2009.04.034

(c) M. Salavati-Niasari, F. Davar, M. Bazarganipour, Dalton Trans. 2010, 39, 7330-7337. https://doi.org/10.1039/b923416k

3. (a) N. Zhang, C.-Y. Huang, D.-H. Shi, Z.-L. You, Inorg. Chem. Commun. 2011, 14, 1636-1639; https://doi.org/10.1016/j.inoche.2011.06.027 (b) L. Z. Zhang, T. Ding, C. L. Chen, M. X. Li, D. Zhang, J. Y. Niu, Russ. J. Coord. Chem. 2011, 37, 356-361; https://doi.org/10.1134/S1070328411040117 (c) N. Patel, H. Parekh, M. Patel, Transition Met. Chem. 2005, 30, 13-17.

4. K. Srinivasan, P. Michaud, J. K. Kochi, J. Am. Chem. Soc. 1986, 108, 2309-2320. https://doi.org/10.1021/ja00269a029

5. (a) H.-H. Li, Z.-L. You, C.-L. Zhang, M. Yang, L.-N. Gao, L. Wang, Inorg. Chem. Commun. 2013, 29, 118-122; https://doi.org/10.1016/j.inoche.2012.12.023

(b) Z.-L. You, D.-M. Xian, M. Zhang, CrystEngComm 2012, 14, 7133-7136; https://doi.org/10.1039/c2ce26201k

(c) M. Zhang, D.-M. Xian, N. Zhang, Z.-L. You, J. Coord. Chem. 2012, 65, 1837-1846;

https://doi.org/10.1080/00958972.2012.684383

(d) X.-S. Zhou, Z.-L. You, D.-M. Xian, D.-P. Dong, Chinese J. Inorg. Chem. 2013, 29, 850-854.

6. M. R. Bermejo, A. Castineiras, J. C. Garcia-Monteagudo, M. Rey, A. Sousa, M. Watkinson, C. A. McAuliffe, R. G. Pritchard, R. L. Beddoes, J. Chem. Soc. Dalton Trans. 1996, 14, 2935-2944. https://doi.org/10.1039/DT9960002935

7. H. Saltzman, J. G. Sharefkin, Organic Syntheses Collect, Vol. V, Wiley, New York, 1973.

8. G. M. Sheldrick, SHELXTL-97, Program for X-ray Crystal Structure Solution, Göttingen (Germany): Univ. of Göttingen, 1997. 
9. G. M. Sheldrick, SADABS, Siemens Area Detector Absorption (and Other) Correction, Göttingen (Germany): Univ. of Göttingen, 1997.

10. W. Zhang, E. N. Jacobsen, J. Org. Chem. 1991, 56, 2296-2298. https://doi.org/10.1021/jo00007a012

11. (a) N. Aurangzeb, C. E. Hulme, C. A. McAuliffe, R. G. Pritchard, M. Watkinson, M. R. Bermejo, A. Sousa, J. Chem. Soc. Chem. Commun. 1994, 18, 2193-2195; https://doi.org/10.1039/c39940002193

(b) M. Watkinson, M. Fondo, M. R. Bermejo, A. Sousa, C. A. McAuliffe, R. G. Pritchard, N. Jaiboon, N. Aurangzeb, M. Naeem, J. Chem. Soc. Dalton Trans. 1999, 1, 31-42; https://doi.org/10.1039/a805555f

(c) Z.-L. You, T. Liu, N. Zhang, M. Zhang, D.-M. Xian, H.H. Li, Inorg. Chem. Commun. 2012, 19, 47-50; https://doi.org/10.1016/j.inoche.2012.01.034

(d) Z.-H. Pan, G.-Q. Zhao, L.-W. Xue, W.-C. Yang, Synth.
React. Inorg. Met.-Org. Nano-Met. Chem. 2016, 46, 17591764; https://doi.org/10.1080/15533174.2015.1137068

(e) X.-M. Hu, G.-Q. Zhao, L.-W. Xue, W.-C. Yang, Inorg. Nano-Met. Chem. 2017, 47, 91-94;

(e) N. Lah, S. Grabner, P. Bukovec, Acta Chim. Slov. 2015, 62, 255-260.

12. M. R. Bermejo, M. Fondo, A. Garcia-Deibe, A. M. Gonzalez, A. Sousa, J. Sanmartin, C. A. McAuliffe, R. G. Pritchard, M. Watkinson, V. Lukov, Inorg. Chim. Acta 1999, 293, 210-217. https://doi.org/10.1016/S0020-1693(99)00260-1

13. E. N. Jacobsen, In: I. Ojima (Ed.), Catalytic Asymmetric Synthesis, VCH, Weinheim, 1993, p. 159.

14. (a) Q. Liu, J. Lin, J. Liu, W. Chen, Y. Cui, Acta Chim. Slov. 2016, 63, 279-286;

(b) M. Liang, D.-H. Zou, Acta Chim. Slov. 2016, 63, 180185. https://doi.org/10.17344/acsi.2015.2169

\section{Povzetek}

Sintetizirali smo dva enojedrna manganova(III) kompleksa s Schiffovo bazo kot ligandom, $\left[\mathrm{MnL}\left(\mathrm{N}_{3}\right)\left(\mathrm{OH}_{2}\right)\right] \cdot \mathrm{CH}_{3} \mathrm{OH}$ (1) in $\left[\mathrm{MnL}(\mathrm{NCS})\left(\mathrm{OH}_{2}\right)\right] \cdot \mathrm{H}_{2} \mathrm{O}(2)$, kjer je L dianion spojine $N, N$ '-bis(5-nitrosaliciliden)etan-1,2-diamin, ter ju okarakterizirali z elementno analizo, IR in UV-Vis spektroskopijo ter z monokristalno rentgensko difrakcijo. Mn atom ima v obeh kompleksih oktaedrično koordinacijo. Molekule kompleksov so povezane preko intermolekularnih vodikovih vezi. Določili smo katalitične lastnosti kompleksov za epoksidacijo stirena z uporabo PhIO in NaOCl kot oksidantov. 